\title{
Improved detection of microbiological pathogens: role of partner and non- governmental organizations
}

\author{
Michael Owusu ${ }^{12^{*}}$ D, Bernard Nkrumah ${ }^{3}$, Godfred Acheampong ${ }^{1}$, Ebenezer Kofi Mensah ${ }^{4}$, \\ Abass Abdul-Karim Komei ${ }^{5}$, Festus Kofi Sroda ${ }^{6}$, Sambian David ${ }^{1}$, Shannon Emery ${ }^{7}$, Lucy Maryogo Robinson ${ }^{7}$, \\ Kwame Asante ${ }^{7}$ and David Opare ${ }^{8}$
}

\begin{abstract}
Background: Proper detection of disease-causing organisms is very critical in controlling the course of outbreaks and avoiding large-scale epidemics. Nonetheless, availability of resources to address these gaps have been difficult due to limited funding. This report sought to highlight the importance of in-country partners and nongovernmental organizations in improving detection of microbiological organisms in Ghanaian Public Health Laboratories (PHLS).

Methods/context: This study was conducted between June, 2018 to August, 2019. U. S CDC engaged the Centre for Health Systems Strengthening (CFHSS) through the Association of Public Health Laboratories to design and implement strategies for strengthening three PHLs in Ghana. An assessment of the three PHLs was done using the WHO/CDS/CSR/ISR/2001.2 assessment tool. Based on findings from the assessments, partner organizations (CFHSS/ APHL/CDC) serviced and procured microbiological equipment, laboratory reagents and logistics. CfHSS provided inhouse mentoring and consultants to assist with capacity building in detection of epidemic-prone infectious pathogens by performing microbiological cultures and antimicrobial susceptibility tests.

Results: A total of 3902 samples were tested: blood (1107), urine (1742), stool (249) and cerebrospinal fluid (CSF) (804). All-inclusive, 593 pathogenic bacteria were isolated from blood cultures (70; 11.8\%); urine cultures (356; 60\%); stool cultures $(19 ; 3.2 \%)$ and from CSF samples $(148 ; 25 \%)$. The most predominant pathogens isolated from blood, urine and stool were Staphylococcus aureus (22/70; 31\%), Escherichia coli (153/356; 43\%) and Vibrio parahaemolyticus $(5 / 19 ; 26.3 \%)$, respectively. In CSF samples, Streptococcus pneumoniae was the most frequent pathogen detected (80/148; 54.1\%). New bacterial species such as Pastuerella pneumotropica, Klebsiella oxytoca, Vibrio parahaemolyticus, and Halfnia alvei were also identified with the aid of Analytical Profile Index (API) kits that were introduced as part of this implementation. Streptococcus pneumoniae and Neisseria meningitidis detections in CSF were highest during the hot dry season. Antimicrobial susceptibility test revealed high rate of S. aureus, K. pneumoniae and E. coli resistance to gentamicin (35-55\%). In urine, E. coli was highly resistant to ciprofloxacin (39.2\%) and ampicillin (34\%).

(Continued on next page)
\end{abstract}

\footnotetext{
* Correspondence: michaelowusu80@gmail.com

${ }^{1}$ Centre for Health Systems Strengthening, Kumasi, Ghana

2Department of Medical Diagnostics, Kwame Nkrumah University of Science and Technology, Kumasi, Ghana

Full list of author information is available at the end of the article
}

(c) The Author(s). 2021 Open Access This article is licensed under a Creative Commons Attribution 4.0 International License, which permits use, sharing, adaptation, distribution and reproduction in any medium or format, as long as you give appropriate credit to the original author(s) and the source, provide a link to the Creative Commons licence, and indicate if changes were made. The images or other third party material in this article are included in the article's Creative Commons licence, unless indicated otherwise in a credit line to the material. If material is not included in the article's Creative Commons licence and your intended use is not permitted by statutory regulation or exceeds the permitted use, you will need to obtain permission directly from the copyright holder. To view a copy of this licence, visit http://creativecommons.org/licenses/by/4.0/ The Creative Commons Public Domain Dedication waiver (http://creativecommons.org/publicdomain/zero/1.0/) applies to the data made available in this article, unless otherwise stated in a credit line to the data. 
(Continued from previous page)

Conclusion: Detection of epidemic-prone pathogens can be greatly improved if laboratory capacity is strengthened. In-country partner organizations are encouraged to support this move to ensure accurate diagnosis of diseases and correct antimicrobial testing.

Keywords: Pathogens, Public health laboratories, Detection, Non-governmental organization

\section{Background}

Globally, the fight against infectious diseases is still a great force to reckon with. The ability of disease-causing organisms to spread beyond national and international borders means an infectious disease threat anywhere is a threat everywhere [1]. Thus, every country has a role to play in making the world safer from epidemics by strengthening its capacity to prevent, detect in timely manner and respond effectively to current and emerging health threats. Key health threats that could likely pose danger to human lives include increasing trend of antimicrobial resistance, zoonotic diseases, biosafety and biosecurity, weak laboratory and surveillance systems and poor work force development.

Addressing the threats of zoonosis, antimicrobial resistance, biosafety and biosecurity begins with detection of aetiological agents involved in disease outbreaks and infections. Timely and accurate detection and reporting of infectious disease outbreaks and events are critical to controlling the course of outbreaks and avoiding largescale epidemics. Detection of microbial pathogens also enables the performance, reporting and surveillance of antimicrobial resistant microbial organisms.

Antimicrobial resistance is one of the biggest threats to global health [2]. According to WHO, there are 12 families of resistant bacteria which pose the greatest threat to human health, and these are termed priority pathogens [3]. These bacteria are further categorized into Priorities 1 (critical), 2 (high) and 3 (medium). Examples of priority 1 pathogens include Carbapenem-resistant Acinetobacter baumannii, Carbapenem-resistant Pseudomonas aeruginosa and Carbapenem-resistant, ESBL-producing Enterobacteriaceae. Priority 2 pathogens include Vancomycin-resistant Enterococcus faecium, Methicillin and Vancomycin-resistant Staphylococcus aureus, Clarithromycin-resistant Helicobacter pylori, Fluoroquinolone-resistant Salmonella spp., Fluoroquinolone-resistant Campylobacter spp., and Cephalosporin-resistant, fluoroquinolone-resistant Neisseria gonorrhoeae. Other bacteria such as Penincillin-non-susceptible Streptococcus pneumoniae, Ampicillin-resistant Hemophilus influenzae, and Fluoroquinolone-resistant Shigella spp. are referred to as Priority 3 pathogens [3]. These resistant pathogens are a threat to global health security because of their potential to cause significant economic and public health problems $[4,5]$.

One of the effective ways to maximize global health security and preparedness for infectious disease threat is to invest in Global Health and address global health security challenges [6]. Since June 2007, various countries have been putting in place efforts to strengthen their International Health Regulations (IHR) core capacities through the Global Health Security expanded activities. As a way of achieving these objectives, WHO conducted a Joint External Evaluation (JEE) of the IHR core capacities in 2017 in Ghana [7]. Among the key findings identified was the need to strengthen laboratory capacities to improve detection of epidemic prone infectious diseases, improve logistics for surveillance, standardize methods for antimicrobial resistance susceptibility testing and improve collaboration between disease surveillance officers and laboratory scientists.

However, availability of human and material resources to address these gaps has been difficult because of funding limitations. Bacterial isolation and identification from clinical specimens such as blood, stool and urine involve the use of sophisticated devices and specialized skills which are expensive [8]. Interventions from partner organizations and non-governmental organizations (NGOs) and/or corporate institutions are needed in the quest to address global health security challenges especially in resource poor settings such as Ghana.

As a way of addressing these challenges, Ghana received funding as one of the high-risk non-Ebola affected countries to strengthen the public health infrastructures and improve detection of epidemic prone infectious pathogens such as Salmonella, Shigella, Vibrio and diarrheagenic E. coli. The U. S Centers of Disease Control and Prevention engaged the Centre for Health Systems Strengthening (CfHSS) through the Association of Public Health Laboratories (APHL) to design and implement strategies for strengthening Public Health Laboratories (PHLs) in Ghana. This report presents a series of activities leading to improved detection of bacterial pathogens in the laboratory.

\section{Methods}

Study setting and design

This was a multicentric-single country retrospective study conducted between June, 2018 and August, 2019. 
The PHLs supported were the Tamale Public Health Laboratory (TPHL), Kumasi Public Health Laboratory (KPHL) and Sekondi Public Health Laboratory (SPHL). These three laboratories are strategically located to serve the three zonal sectors of Ghana (Fig. 1). KPHL serves the Ashanti region and other southern parts of Ghana. TPHL serves the five northern regions (Savannah, North-East, Northern, Upper East and Upper West) in Ghana and SPHL serves the Western and Central regions of Ghana. All three laboratories are situated on the premises of tertiary health facilities: KPHL is located on the premises of Ashanti regional hospital in Kumasi; TPHL is located very close to the Tamale Teaching Hospital; and SPHL is found on the same environment as the Effia-Nkwanta regional hospital. The laboratories work closely with these hospitals, and invasive procedures such as lumbar punctures are performed by trained clinicians and physician assistants at the various hospitals and samples transported on ice packs to the PHL for laboratory testing. These laboratories are the

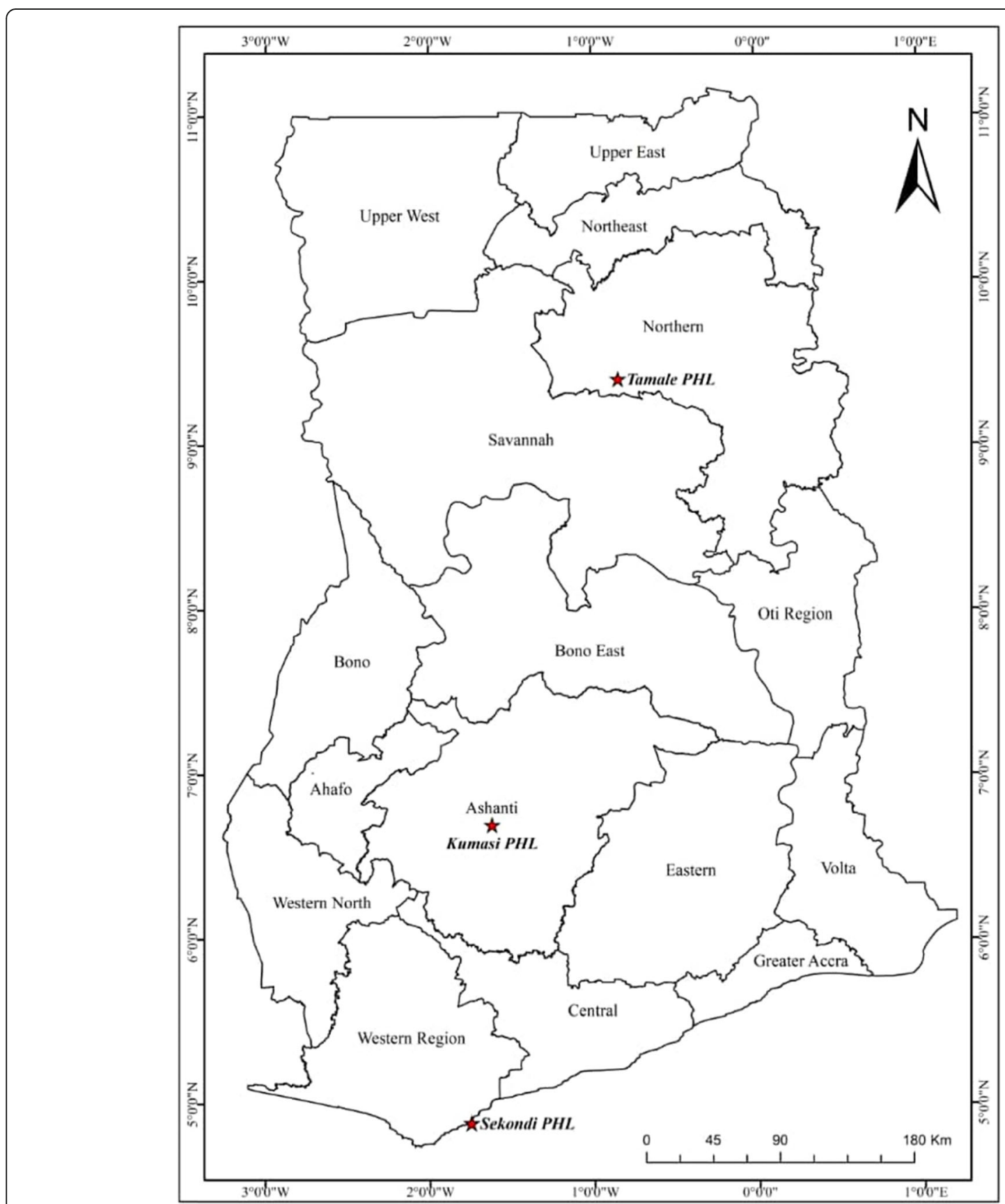

Fig. 1 Zonal Public Health Laboratories (black dots) selected for capacity building 
first point of call during outbreak situations and they perform range of diagnostic testing, but with limited capacity and infrastructure.

\section{Study population}

Study population comprised individuals of all ages and gender who attended the various hospitals and exhibited clinical presentations of sepsis, gastroenteritis, urinary tract infection and meningitis. Blood and stool cultures were requested by clinicians from individuals with presumptive symptoms of sepsis and gastroenteritis [9]. Urine was collected from individuals who presented with symptoms such as frequent painful urination, hematuria and cloudy/foul-smelling urine for urine culture. Patients with classical case definition for meningitis were referred to trained clinicians for lumbar puncture. The clinical criteria required for lumbar puncture to be performed comprised sudden onset of fever (axillary: > $38^{\circ} \mathrm{C}$ ), and at least two of the following clinical symptoms: neck pain, neck stiffness, photophobia, reduced level of consciousness, bulging fontanelle, and fits/partial seizures in children between 6 months and 5 years [9, $10]$.

\section{Quality assessment prior to start of study}

Prior to initiating the programme, we conducted laboratory assessments of the three PHLs using the WHO/ CDS/CSR/ISR/2001.2 assessment tool. The assessment evaluated areas including availability of microbiological equipment, scope of laboratory investigations, specimen transportation and handling, adequacy of standard operating procedures (SOPs), internal and external quality assurance and general work flow.

Based on findings from the assessments, in-house mentors and consultants were recruited by CfHSS to assist with capacity building in microbiological investigations and quality management system (QMS). Consultants and mentors assisted in review of SOPs of the laboratories, training laboratory staff on new microbiological techniques such as use of Analytical Profile Index (API), standardizing methods of media preparation and antimicrobial susceptibility testing, establishing sheep farms for blood and chocolate media preparation and training of laboratory staff and disease surveillance officers in the handling, collection and transportation of infectious samples. APHL also established an external quality assurance programme and also supported the procurement of equipment and reagents for smooth operation of the laboratories.

\section{Ethical approval}

Permission was sought from the facilities before collection of this data. All protocols related to data collection and analysis were reviewed and approved by the Ethics
Review Committee (ERC) of the Ghana Health Service (GHS) (Approval number: GHS-ERC008/03/20).

\section{Interventions}

As part of the design of this capacity building programme, we focused on improving capacity in the detection of epidemic-prone infectious pathogens such as Salmonella, Shigella, Vibrio and diarrhegenic E. coli. Samples such as blood, urine, stool and cerebrospinal fluid (CSF) were given priority. Laboratory staff and disease surveillance officers were adequately trained in collection and transportation of priority specimen from the field to the laboratory under cold chain. As part of the training, SOPs related to specimen transportation, processing and pathogen detection were developed/revised for each of the laboratory sites. QMS were also improved and staff were assigned to specific tasks in line with objectives of the programme.

\section{Laboratory methods for detection of priority pathogens}

Blood samples collected into culture bottles (BD, Franklin Lakes, NJ, USA) were incubated in BACTEC ${ }^{\mathrm{Tm}} 9050$ (for TPHL) or BACTEC FX 40 (for SPHL and KPHL) blood culture systems (BD, Franklin Lakes, NJ, USA). Samples were incubated at $35^{\circ} \mathrm{C}$ for five days or until a positive signal was detected. Positive blood culture samples were plated on blood and chocolate agar (BD, Franklin Lakes, NJ, USA) and incubated overnight (18$24 \mathrm{~h}$ ) at $35-37^{\circ} \mathrm{C}$. Urine samples were plated directly onto cysteine lactose electrolyte-deficient (CLED) agar (BD, Franklin Lakes, NJ, USA), and stool samples plated on xylose lysine deoxycholate (XLD), mannitol salt agar (MSA), thiosulphate citrate bile salt sucrose (TCBS), and sorbitol-MacConkey agars (SMAC) (BD, Franklin Lakes, NJ, USA). Both urine and stool samples were incubated overnight $(18-24 \mathrm{~h})$ at $35-37^{\circ} \mathrm{C}$.

At all PHL sites, CSF samples were cultured for detection of bacteria pathogens by plating directly on blood and chocolate agars and incubated afterwards at 35$37^{\circ} \mathrm{C}$ aerobically and anaerobically, respectively. Gram stain was also performed immediately on all CSF samples for prompt reporting for patient management. At TPHL, multiplex real-time polymerase chain reaction (PCR) was conducted on all CSF samples for further identification and confirmation. Samples were processed after which Mastermix comprising of primers, probes and other reagents were used for simultaneous detection of Neisseria meningitidis, Haemophilus influenzae and Streptococcus pneumoniae. One microlitre $(1 \mu \mathrm{l})$ each of sodC-forward primer, sodC-Reverse primer, sodC-Probe, hpd3-Forward primer, hpd3-Reverse primer, hpd3Probe, lytA-forward primer, lytA-Reverse primer, lytAProbe was added to $1.5 \mu \mathrm{l}$ of PCR grade water, $12.5 \mu \mathrm{l}$ PCR quantabio and $2 \mu \mathrm{l}$ of DNA template which resulted 
in a total reaction volume of $25 \mu \mathrm{l}$. PCR amplification was conducted using AriaMx RT-PCR System (Agilent Technologies). Thermal cycling conditions comprised one cycle of initial denaturation at $95^{\circ} \mathrm{C}$ for $10 \mathrm{~min}$, followed by 40 cycles of template denaturation at $95^{\circ} \mathrm{C}$ for $15 \mathrm{~s}$ and annealing at $60^{\circ} \mathrm{C}$ for $1 \mathrm{~min}$.

\section{Bacteria identification}

For positive blood culture, a single pure colony was picked from the blood agar for Gram staining. Urine cultures which yielded significant bacteria growth on CLED was selected for Gram staining by picking single well isolated colony. For positive stool culture, colonies which grew on XLD, MSA, TCBS and SMAC agars were sub-cultured onto different blood agars and incubated overnight aerobically. Single pure colonies on the respective blood agars were picked for Gram staining.

Biochemical investigations such as triple sugar iron (TSI), citrate, urease, indole and oxidase tests were performed on all Gram-negative isolates. API 20E and $20 \mathrm{NE}$ were also performed on presumptive enterobacteria and non-enterobacterial isolates, respectively. Other tests such as catalase, coagulase and optochin were performed on all Gram-positive bacteria to aid identification of most common Gram-positive pathogens such as Streptococcus pneumoniae and Staphylococcus aureus.

\section{Antimicrobial susceptibility testing (AST)}

The antibiotics chosen for testing were based on current treatment regimens for Gram-negative and Grampositive infections in Ghana as well as clinical and laboratory standards institute guidelines (CLSI) [11]. Gram-negative bacteria susceptibility to ampicillin $(10 \mu \mathrm{g})$, amoxiclav (amoxicillin \& clavulanic acid; 20/ $10 \mu \mathrm{g})$, ceftriaxone $(30 \mu \mathrm{g})$, cefuroxime $(30 \mu \mathrm{g})$, azithromycin $(15 \mu \mathrm{g})$, amikacin $(30 \mu \mathrm{g})$, meropenem $(10 \mu \mathrm{g})$, trimethoprim/sulfamethoxazole $(1.25 / 23.75 \mu \mathrm{g})$, ciprofloxacin $(5 \mu \mathrm{g})$, gentamicin $(10 \mu \mathrm{g})$, tetracycline $(30 \mu \mathrm{g})$, chloramphenicol $(30 \mu \mathrm{g})$, ceftazidime $(30 \mu \mathrm{g})$, cefotaxime $(30 \mu \mathrm{g})$ and nalidixic acid $(30 \mu \mathrm{g})$ was tested on Mueller-Hinton agar (BD, Franklin Lakes, NJ, USA) using the Kirby-Bauer disc diffusion method. Grampositive bacteria were also tested against ampicillin $(10 \mu \mathrm{g})$, amoxiclav $(20 / 10 \mu \mathrm{g})$, ceftriaxone $(30 \mu \mathrm{g})$, azithromycin $(15 \mu \mathrm{g})$, ciprofloxacin $(5 \mu \mathrm{g})$, gentamicin $(10 \mu \mathrm{g})$, tetracycline $(30 \mu \mathrm{g})$, chloramphenicol $(30 \mu \mathrm{g})$, cefotaxime $(30 \mu \mathrm{g})$, amikacin $(30 \mu \mathrm{g})$ together with erythromycin $(15 \mu \mathrm{g})$, penicillin (10 units) and clindamycin $(2 \mu \mathrm{g})$. The breakpoints for the antibiotics used were in line with CLSI 2018 guidelines [11].

\section{Statistical analysis}

Data were collected, entered into Microsoft excel (Microsoft Cooperation, 2013), cleaned and exported to
STATA version 12 (Stata Corp, College Station, Texas, USA) for analysis. Descriptive statistics was used to summarize the distribution of various variables into table and graphs. Differences between discrete variables were analyzed using chi-square (or Fisher's exact where appropriate) and $p$ value less than 0.05 was considered statistically significant.

\section{Results}

\section{Characteristics of study population}

A total of 3902 patients were tested in all 3 PHLs of which 2229 (57.1\%) were females. The median age of all patients was 18 years (IQR: 3-36 years). There was general increase in total number of samples collected and processed after the programme implementation compared to samples received before implementation across all three PHLs (Table 1). At TPHL, there was statistically significant difference in collection of all samples except blood before and after initiation of programme. Blood, urine and stool were significantly collected at KPHL, whereas in SPHL, only stool specimen was significantly collected before and after programme initiation.

\section{Sampling trend}

The number of blood samples collected in June, 2018 (inception of study) was the lowest (39/1107; 3.5\%) recorded throughout the study period. Sample collection improved with time and remained fairly constant till the end of the study (August 2019), with average number of blood samples collected per month to be 74 (6.7\%).

Urine was the most collected sample (1742/3903; $44.6 \%)$ among all the specimens. The average number of urine samples collected for each month was 116 (6.6\%). Generally, there was a downward trend of urine samples collected from November 2018 to March 2019 (Dry Season), with December 2018 recording the least number (77/1743; 4.4\%) collected.

Total number of stool samples collected over the study period was comparatively low $(249 / 3903 ; 6.4 \%)$, with an average of 17 samples collected every month. There was a sharp rise in CSF samples collected from January 2019 to March 2019 (Dry Season) (Fig. 2).

\section{Bacterial pathogen distribution}

Bacterial pathogens were detected in five hundred and ninety-three (593) out of 3902 clinical specimens. Generally, before programme initiation, there were low proportions of bacterial isolates recovered from the clinical specimens across all three PHLs (except for bacteria from CSF identified by PCR at TPHL) as shown in Table 2. Of the 593 isolates, bacterial pathogens were identified in $70(11.8 \%)$ blood cultures, $356(60 \%)$ urine cultures, 19 (3.2\%) stool cultures and 148 (25\%) CSF samples after programme implementation (Table 2). 
Table 1 Distribution of sample types collected at the various PHLS

\begin{tabular}{|c|c|c|c|c|c|c|c|c|c|}
\hline & \multicolumn{2}{|l|}{ TPHL [n (\%)] } & \multirow[b]{2}{*}{ p-value } & \multicolumn{2}{|l|}{ KPHL [n (\%)] } & \multirow[b]{2}{*}{$p$-value } & \multicolumn{2}{|l|}{ SPHL [n (\%)] } & \multirow[b]{2}{*}{$p$-value } \\
\hline & Before (838) & After (961) & & Before (394) & After (705) & & Before (1621) & After (2236) & \\
\hline Blood & $78(9.3)$ & 115 (12.0) & 0.07 & $90(22.8)$ & $99(14.0)$ & $<0.001$ & 679 (41.9) & 893 (39.9) & 0.224 \\
\hline Urine & $126(15.0)$ & $96(10.0)$ & 0.001 & $243(61.7)$ & $509(72.2)$ & $<0.001$ & $855(52.7)$ & $1137(50.8)$ & 0.245 \\
\hline Stool & $80(9.5)$ & $26(2.7)$ & $<0.001$ & $61(15.5)$ & $39(5.5)$ & $<0.001$ & $66(4.1)$ & $184(8.2)$ & $<0.001$ \\
\hline CSF & $554(66.1)$ & $724(75.3)$ & $<0.001$ & - & $58(8.2)$ & - & $21(1.3)$ & $22(1.0)$ & 0.363 \\
\hline
\end{tabular}

'Before' refers to number of samples which arrived at the various PHLs before implementation of the programme; 'After' refers to number of samples which arrived at the various PHLs after implementation of the programme

There were more bacteria isolated from blood and urine after programme implementation compared to before at SPHL and this difference was statistically significant. Bacteria isolated from urine after programme implementation was disproportionately higher than before but the difference was not significant. After implementation, only $6(0.1 \%)$ samples were contaminated with Coagulase-negative Staphylococci (CNS) and these emanated from blood (2) and urine (4).

The most predominant bacterial pathogen isolated from blood was Staphylococcus aureus (22/70; 31\%) (Table 3). Escherichia coli was commonly found in the urine samples (153/356; 43\%) and Vibrio parahaemolyticus was high in stool $(5 / 19 ; 26.3 \%)$. There were 3 main pathogens identified in the CSF samples - Neisseria meningitidis, Streptococcus pneumoniae and Hemophilus influenzae, with S. pneumoniae being the most isolated pathogen (80/148; 54.1\%).

$S$. aureus was commonly isolated from the blood of patients in SPHL $(n=13)$, followed by TPHL $(n=9)$, with no isolation from KPHL. E. coli causing urinary tract infection (UTI) were mostly isolated from individuals in SPHL $(n=74)$, followed by KPHL $(n=63)$ and then TPHL $(n=16)$. Isolation of bacteria causing meningitis was extremely high in CSF specimens of patients who attended TPHL (151/154; 98.1\%). We observed that new pathogens such as Pastuerella pneumotropica, Klebsiella oxytoca, Vibrio parahaemolyticus, Enterobacter aerogenes, Halfnia alvei, Serratia odonfera1 and Citrobacter freundii were identified with the aid of API. Hitherto, these pathogens had never been isolated in any of the three PHLs.

\section{Seasonal variations in prevalence of bacterial pathogens} Ghana has two seasons: dry and wet seasons. The wet season is from April to mid-October and the dry season is from December to March. Detection of pathogens from the blood during the first four months of the study was relatively lower compared to the months afterwards (Fig. 3). There was high isolation of S. aureus and Salmonella spp. from blood samples in the dry season. The wet season mostly had Klebsiella spp. been isolated. There was a steady rise in Streptococcus pneumoniae and Neisseria meningitidis detection from CSF in the dry season. Streptococcus pneumoniae isolates mostly

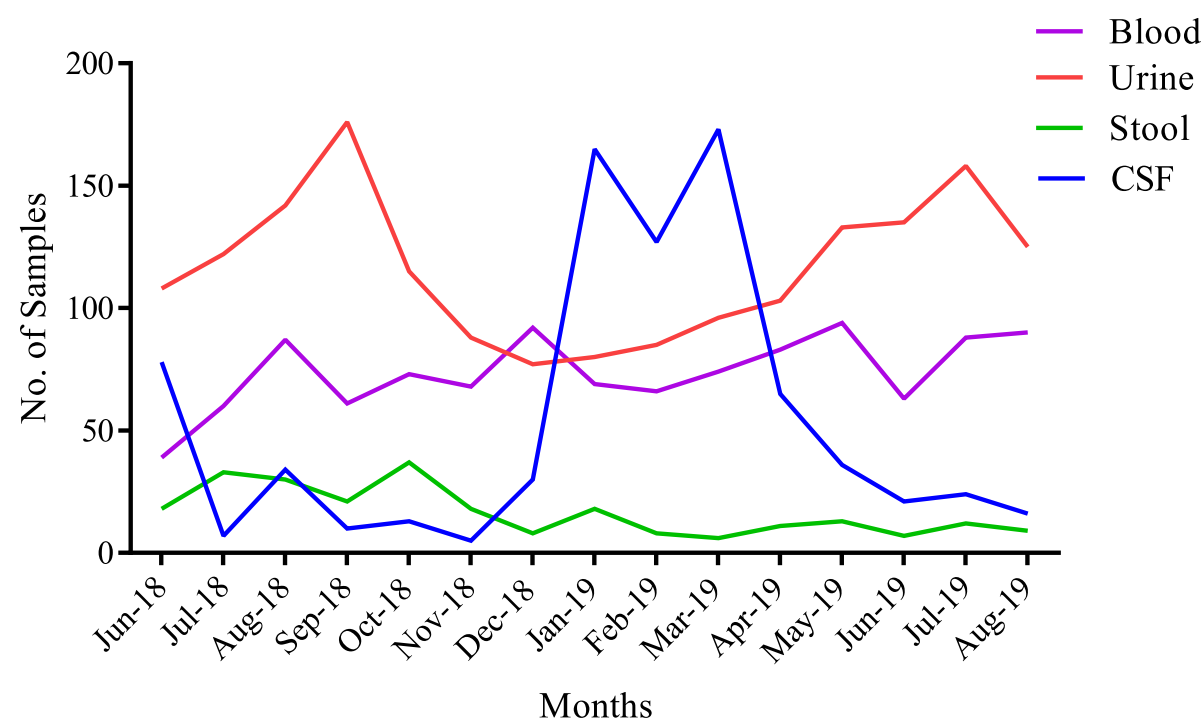

Fig. 2 A description of the sampling trend for the duration of this project (June 2018-August 2019) 
Table 2 Distribution of bacterial pathogens among the study sites

\begin{tabular}{|c|c|c|c|c|c|c|c|c|c|}
\hline & \multicolumn{2}{|l|}{ TPHL [n (\%)] } & \multirow[b]{2}{*}{$p$-value } & \multicolumn{2}{|l|}{ KPHL [n (\%)] } & \multirow[b]{2}{*}{$p$-value } & \multicolumn{2}{|l|}{ SPHL [n (\%)] } & \multirow[b]{2}{*}{$p$-value } \\
\hline & Before (192) & After (203) & & Before (36) & After (175) & & Before (96) & After (215) & \\
\hline Blood & $2(1.0)$ & $17(8.4)$ & $<0.001$ & 0 & $10(5.7)$ & 0.14 & $1(1.0)$ & $43(20.0)$ & $<0.001$ \\
\hline Urine & $14(7.3)$ & $41(20.2)$ & $<0.001$ & 36 & $156(89.1)$ & 0.04 & $91(94.8)$ & $159(74.0)$ & $<0.001$ \\
\hline Stool & $7(3.6)$ & 0 & 0.01 & 0 & $7(4.0)$ & 0.22 & $2(2.1)$ & $12(5.6)$ & 0.169 \\
\hline CSF & $169(88.0)$ & $145(71.4)$ & $<0.001$ & - & $2(1.1)$ & - & $2(2.1)$ & $1(0.5)$ & 0.177 \\
\hline
\end{tabular}

'Before' refers to number of bacterial pathogens identified at the various PHLs before implementation of the programme; 'After' refers to number of bacterial pathogens which were indentified at the various PHLs after implementation of the programme

occurred in January and co-detections of Streptococcus pneumoniae and Neisseria meningitidis occurred in March (Fig. 4). Urinary pathogens did not show any particular seasonality. However, high isolations of E. coli occurred mostly in the wet season as compared to the dry season (Fig. 4).

\section{Effects of socio-demographics on bacterial infection}

Females were more likely to contract urinary tract infection than males (Table $4 ; p<0.01$ ). Nonetheless, gender did not significantly contribute to the likelihood of having bacterial infection from blood, stool and/or CSF. Again, children less than 18 years were more prone to bacterial infection in the blood and CSF than the adults (Table 4). On the other hand, urinary tract infection (UTI) in adults were significantly higher than in children.

\section{Antimicrobial susceptibility results Blood}

Overall, gentamicin was the least effective antibiotic with 35-55\% of S. aureus, K. pneumoniae and E. coli bacteria resistant to this antibiotic (Table 5). Salmonella spp. showed high proportion of resistance to ampicillin, cefuroxime and ciprofloxacin (38.5\%) but not to azithromycin, tetracycline, and cefotaxime (7.7\%).

\section{Urine}

E. coli recorded high resistance to ciprofloxacin (39.2\%) and ampicillin (34.0\%) (Table 5). Klebsiella spp. was highly resistant to the 3 rd generation cephalosporin cefotaxime (39.7\%), followed by ceftriaxone (31.5\%) and then gentamicin (31.5\%). Strains of Staphylococcus spp. and Citrobacter spp. were found to show high resistance to ciprofloxacin (39 and 52\%, respectively). Half of the Pseudomonas spp. isolated from urine were resistant to cefotaxime. Likewise, almost half of Proteus spp. found in urine were resistant to cefotaxime and nalidixic acid (46.7\%) (Table 5).

\section{Discussion}

The role microbiological laboratories play in the detection and surveillance of pathogenic bacteria is important in addressing the global health security threats posed by infectious agents. Resourcing of the PHLs with equipment, reagents and human resource capacity building have enabled the increased and accurate detection of bacterial pathogens from clinical specimens of blood, stool, urine and cerebro-spinal fluid at three different PHLs in Ghana. It is instructive to note that prior to this programme, TPHL and KPHL for instance had stopped blood cultures due to unavailability of logistics and nonfunctional BACTEC equipment. SPHL as well was not well-versed in the use of CLSI standards for isolation of bacteria. Adequate measures including provision of distilled water plants, establishments of sheep farms, training in microbiological media preparation and identification of microbial pathogens were put in place. Training and adequate resourcing are therefore essential in strengthening the capacity and functional role of PHLs in developing countries.

In sub-Saharan Africa (sSA), about 12 million people die each year [12], with the causes of deaths largely due to undiagnosed infectious diseases such as HIV, malaria and tuberculosis [13]. A study in Kenya found that bacterial bloodstream infection diagnosed only by blood culture accounted for $26 \%$ of deaths among children [14], which gives credence to the fact that laboratory diagnosis of bacterial infections needs to be strengthened in sub-Sahara Africa. In line with previous studies in Africa [15, 16], Gram-negative bacteria predominated in our study. Infections from Gram-negative bacteria pose significant public health problems and this is mainly due to high resistance to antimicrobial agents [17]. Prior to implementation of the project, all three PHLs had serious challenges with regards to microbiological detection of bacterial pathogens from clinical specimens. At TPHL, identification was solely done by observing morphological characteristics of the colonies which grew on various culture media. There was absence of biochemical testing and automated blood culture system due to logistical and technical constraints. Both KPHL and SPHL performed very limited biochemical tests, and only SPHL performed automated blood culture analysis. Across the three PHLs, identification of suspected bacterial pathogens was performed up to the Genus level. All these 
Table 3 Laboratory investigation on results from bacterial isolates

\begin{tabular}{|c|c|c|c|c|}
\hline \multirow[t]{2}{*}{ Laboratory results } & \multicolumn{3}{|c|}{ Study sites } & \multirow[b]{2}{*}{ Tota } \\
\hline & TPHL & KPHL & SPHL & \\
\hline \multicolumn{5}{|l|}{ Blood culture $(\mathrm{BC})$ results } \\
\hline Total BC performed & 115 & 99 & 893 & 1107 \\
\hline Total BC pathogens & 17 & 10 & 43 & 70 \\
\hline Escherichia coli & 3 & 3 & 3 & 9 \\
\hline Klebsiella pneumoniae & 4 & 2 & 2 & 8 \\
\hline Klebsiella aerogenes & 0 & 1 & 0 & 1 \\
\hline Klebsiella spp. & 0 & 1 & 4 & 5 \\
\hline Pseudomonas aeruginosa & 1 & 2 & 2 & 5 \\
\hline Salmonella spp. & 0 & 0 & 5 & 5 \\
\hline Salmonella Typhi & 0 & 0 & 8 & 8 \\
\hline Staphylococcus aureus & 9 & 0 & 13 & 22 \\
\hline Others & 0 & 1 & 6 & 7 \\
\hline \multicolumn{5}{|l|}{ Urine culture $(U C)$ results } \\
\hline Total UC performed & 96 & 509 & 1137 & 1742 \\
\hline Total UC pathogens & 41 & 156 & 159 & 356 \\
\hline Escherichia coli & 16 & 63 & 74 & 153 \\
\hline Pseudomonas spp. & 0 & 11 & 0 & 11 \\
\hline Pseudomonas aeruginosa & 0 & 7 & 3 & 10 \\
\hline Proteus vulgaris & 1 & 4 & 1 & 6 \\
\hline Proteus mirabilis & 0 & 5 & 0 & 5 \\
\hline Proteus spp. & 0 & 4 & 0 & 4 \\
\hline Klebsiella pneumoniae & 5 & 8 & 0 & 13 \\
\hline Klebsiella oxytoca & 0 & 1 & 0 & 1 \\
\hline Klebsiella spp. & 0 & 27 & 32 & 59 \\
\hline Citrobacter spp. & 1 & 3 & 21 & 25 \\
\hline Staphylococcus aureus & 8 & 4 & 4 & 16 \\
\hline S. saprophyticus & 1 & 10 & 11 & 22 \\
\hline Others & 9 & 11 & 13 & 33 \\
\hline \multicolumn{5}{|l|}{ Stool culture (SC) results } \\
\hline Total SC performed & 26 & 39 & 184 & 249 \\
\hline Total SC pathogens & 0 & 7 & 12 & 19 \\
\hline EHEC 0157:H7 & 0 & 3 & 0 & 3 \\
\hline Staphylococcus aureus & 0 & 2 & 0 & 2 \\
\hline Shigella spp. & 0 & 0 & 3 & 3 \\
\hline Vibrio parahaemolyticus & 0 & 0 & 5 & 5 \\
\hline Others & 0 & 2 & 4 & 6 \\
\hline \multicolumn{5}{|c|}{ Cerebrospinal fluid (CSF) PCR results } \\
\hline Total PCR performed & 724 & 58 & 22 & 804 \\
\hline Total pathogens & 145 & 2 & 1 & 148 \\
\hline Neisseria meningitidis & 61 & 1 & 1 & 63 \\
\hline Streptococcus pneumoniae & 80 & 1 & 0 & 81 \\
\hline Hemophilus influenzae & 10 & 0 & 0 & 10 \\
\hline
\end{tabular}

hindered the identification process and proper administration of antimicrobials, which might directly or indirectly contribute to increasing rate of antimicrobial resistance globally. Procurement and maintenance of automated blood culture machines for the PHLs and training of staffs on its use resulted in an increased rate of blood samples received for blood culture. Reagents necessary for biochemical tests were also procured for all the PHLs and staffs were trained on the use and interpretation of tests such as triple sugar iron (TSI), citrate, indole, catalase, urease, coagulase and catalase tests. Analytical profile index and serotyping were also introduced to all PHLs which served as confirmatory tests for identification of some microbial pathogens. All these led to a significant upsurge in bacterial detection (Table 3) which hitherto could have easily been overlooked and missed.

Staphylococcus aureus was the most prevalent bacteria found in the blood. Naber reported that $S$. aureus is a major cause of bacteremia, and it is associated with higher morbidity and mortality, compared with bacteremia caused by other pathogens [18]. Again, lifethreatening complications from $S$. aureus bloodstream infections such as infective endocarditis and metastatic infections could occur $[19,20]$, and these complications place high resource burden on health-care systems [21]. Without quality laboratory testing, detection of this medically relevant organism could not be done, and this would have a devastating clinical outcome on the patients. However, in this crisis time, laboratory and healthcare infrastructures are woefully inadequate to meet the pressing needs and/or perhaps have been ignored in several areas of sSA [22]. More often than not, a lot of financial resources from funding organizations are channeled to prevention of diseases and patients' care, whereas building of laboratory capacity receives relatively little financial support [23].

E. coli and $V$. parahaemolyticus were commonly isolated pathogens from urine and stool cultures, respectively. Other common pathogens detected in urine included Klebsiella spp., Citrobacter spp., Staphylococcus saprophyticus and Staphylococcus aureus. UTI is among the leading causes of morbidity and mortality and inappropriate diagnosis could lead to treatment failures and additional complications [24]. This study showed that females were more likely to contract UTI than males, consistent with findings from rural Nigeria [25] and other parts of the world [26, 27]. In women, UTIs are one of the most frequent clinical bacterial infections, constituting about 25\% of all infections [28]. This is mainly due to women having extremely short urethra, very close to the anal region, where several enterobacteria are shed frequently in stool. Other factors thought to predispose women to recurrent UTIs include voiding 


\section{Blood}

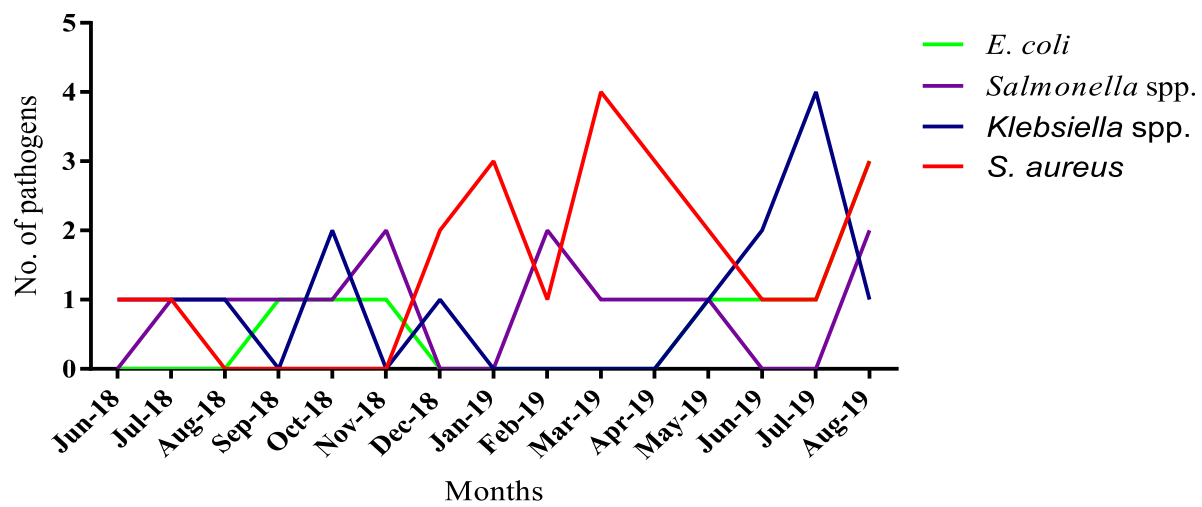

Fig. 3 Seasonality of blood culture isolates

patterns pre- and post-coitus, wiping techniques, wearing tight undergarments, and vaginal douching; however, there is no proven association [29]. Also, medical conditions such as pregnancy, diabetes mellitus and immunosuppression increase risk of women having UTI [30]. Cases of $V$. parahaemolyticus infection are few globally; however, it is a common cause of bacterial gastroenteritis in Asia, especially in Japan [31]. Transmission of $V$. parahaemolyticus is mainly through the consumption of infected seafood causing acute gastroenteritis [32]. The organism can also make its way into an open wound during exposure to salt water [31]. All $V$. parahaemolyticus cases recorded in this study were from SPHL; located in the only coastal and southernmost region in this study where consumption of raw/undercooked seafoods is high. SPHL received the most specimens,

\section{Urine}

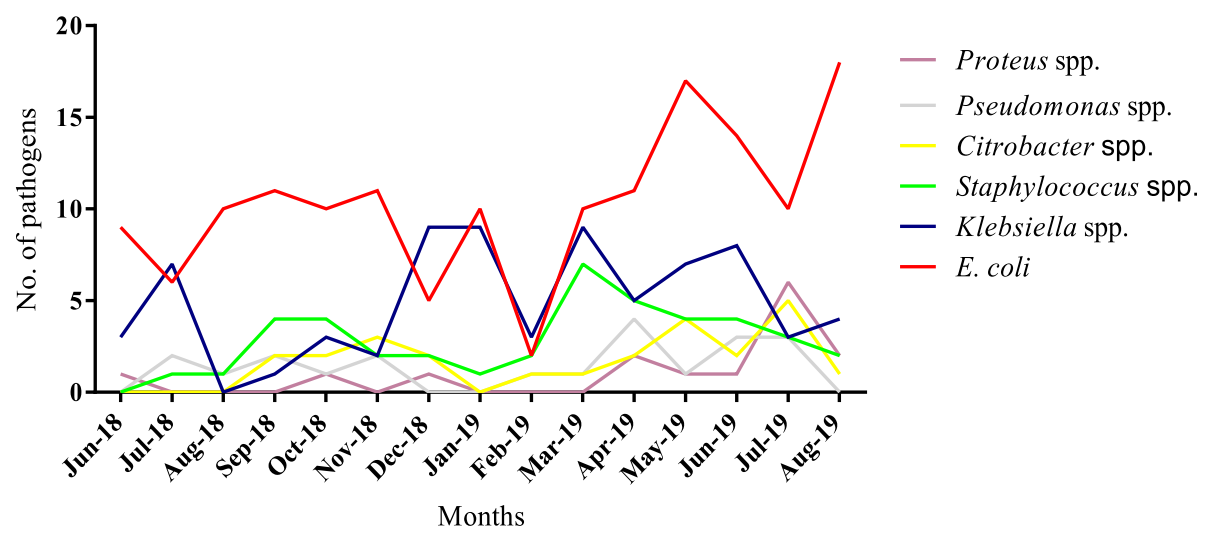

CSF

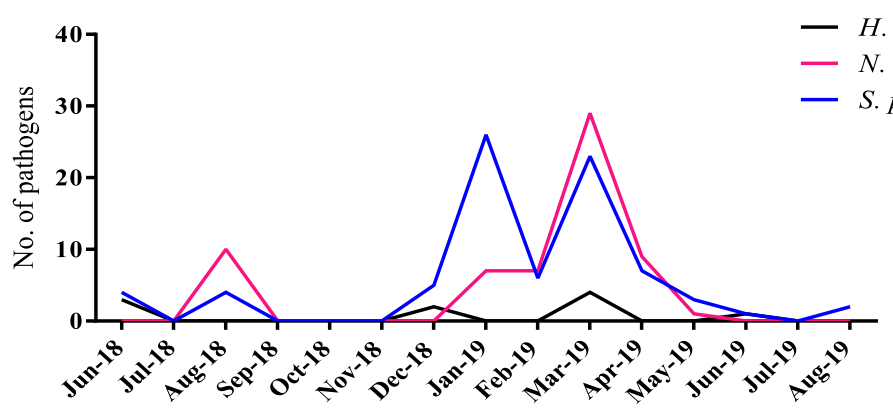

Months

Fig. 4 Seasonality of isolates in Urine and CSF 
Table 4 Bacterial infections according to age and gender

\begin{tabular}{|c|c|c|c|c|}
\hline \multirow[b]{2}{*}{ Variable } & \multicolumn{4}{|c|}{ Sample [n (\%)] } \\
\hline & Blood & Urine & Stool & CSF \\
\hline \multicolumn{5}{|l|}{ Sex } \\
\hline M & $35(50)$ & 95 (26.5) & $7(36.8)$ & $79(54.1)$ \\
\hline $\mathrm{F}$ & $35(50)$ & $263(73.5)$ & $12(63.2)$ & $67(45.9)$ \\
\hline$p$-value & 0.51 & $<0.01$ & 0.65 & 0.21 \\
\hline \multicolumn{5}{|c|}{ Age (years) } \\
\hline $0-5$ & $16(22.9)$ & $64(17.9)$ & $2(10.5)$ & $25(16.9)$ \\
\hline $6-18$ & $9(12.9)$ & $47(13.1)$ & 0 & $46(31.1)$ \\
\hline$>18$ & $45(64.2)$ & $247(69)$ & 17 (89.5) & $77(52)$ \\
\hline$p$-value & 0.52 & 0.07 & 0.15 & 0.62 \\
\hline
\end{tabular}

because of its strategic location within the enclave of the South-Western part of Ghana. As a result, clinicians could easily refer patients to the laboratory for culture analysis. Inhabitants living along the coast principally engage in numerous outdoor activities such as fish farming and swimming in the deep ocean which predispose them to some waterborne infections, especially urinary tract infections (UTIs), and this could also account for the high proportions of urine samples collected in SPHL compared to the other PHLs.

Most detections of S. pneumoniae, $H$. influenzae and $N$. meningitidis in this study were achieved by multiplex real-time PCR. This platform was however only available at the TPHL, which also doubles as a reference testing centre for meningitis in Ghana. It is possible the other

Table 5 Antimicrobial susceptibility patterns of most common bacterial pathogens

\begin{tabular}{|c|c|c|c|c|c|c|c|c|c|c|c|c|}
\hline \multicolumn{13}{|c|}{ Proportion of resistant bacterial species [n (\%)] } \\
\hline & \multicolumn{5}{|l|}{ Blood } & \multicolumn{7}{|l|}{ Urine } \\
\hline & $\begin{array}{l}\text { S. aureus } \\
(n=22)\end{array}$ & $\begin{array}{l}\text { Klebsiella } \\
\text { spp. }(n= \\
14)\end{array}$ & $\begin{array}{l}\text { Salmonella } \\
\text { spp. }(n=13)\end{array}$ & $\begin{array}{l}\text { E. coli } \\
(\mathrm{n}=9)\end{array}$ & $\begin{array}{l}p- \\
\text { value }\end{array}$ & $\begin{array}{l}\text { E. coli } \\
(n= \\
153)\end{array}$ & $\begin{array}{l}\text { Klebsiella } \\
\text { spp. }(n= \\
73)\end{array}$ & $\begin{array}{l}\text { Staphylococcus } \\
\text { spp. }(n=41)\end{array}$ & $\begin{array}{l}\text { Citrobacter } \\
\text { spp. }(n=25)\end{array}$ & $\begin{array}{l}\text { Pseudomonas } \\
\text { spp. }(n=21)\end{array}$ & $\begin{array}{l}\text { Proteus } \\
\text { spp. }(\mathrm{n}= \\
15)\end{array}$ & $\begin{array}{l}p- \\
\text { value }\end{array}$ \\
\hline AMP & $4(18.2)$ & $6(42.9)$ & $5(38.5)$ & $\begin{array}{l}2 \\
(22.2)\end{array}$ & 0.348 & $\begin{array}{l}52 \\
(34.0)\end{array}$ & $18(24.7)$ & $4(9.8)$ & $8(32.0)$ & - & $1(6.7)$ & 0.006 \\
\hline AMC & $1(4.5)$ & $1(7.1)$ & 0 & 0 & 0.696 & $\begin{array}{l}16 \\
(10.5)\end{array}$ & $7(9.6)$ & $3(7.3)$ & $7(28.0)$ & $3(14.3)$ & $1(6.7)$ & 0.084 \\
\hline CRO & $2(9.1)$ & $4(28.6)$ & $2(15.4)$ & $\begin{array}{l}3 \\
(33.3)\end{array}$ & 0.314 & $\begin{array}{l}49 \\
(32.0)\end{array}$ & $23(31.5)$ & $8(19.5)$ & $9(36.0)$ & $7(33.3)$ & $5(33.3)$ & 0.671 \\
\hline CXM & - & $2(14.3)$ & $5(38.5)$ & 0 & 0.074 & $\begin{array}{l}41 \\
(26.8)\end{array}$ & $17(23.3)$ & $2(4.9)$ & $5(20.0)$ & $6(28.6)$ & $4(26.7)$ & 0.042 \\
\hline AZM & $2(9.1)$ & 0 & $1(7.7)$ & - & 0.607 & $15(9.8)$ & $3(4.1)$ & $5(12.2)$ & $1(4.0)$ & - & $1(6.7)$ & 0.460 \\
\hline MEM & - & 0 & - & - & - & 0 & 0 & - & 0 & $2(9.5)$ & 0 & 0.008 \\
\hline SXT & 0 & $1(7.1)$ & 0 & 0 & 0.621 & $8(5.2)$ & $6(8.2)$ & $3(7.3)$ & $2(8.0)$ & $2(9.5)$ & 0 & 0.779 \\
\hline CIP & $6(27.3)$ & $2(14.3)$ & $5(38.5)$ & $\begin{array}{l}4 \\
(44.4)\end{array}$ & 0.360 & $\begin{array}{l}60 \\
(39.2)\end{array}$ & $22(30.1)$ & $16(39.0)$ & $13(52.0)$ & $4(19.0)$ & $6(40.0)$ & 0.200 \\
\hline GEN & $12(54.5)$ & $5(35.7)$ & $3(23.1)$ & $\begin{array}{l}4 \\
(44.4)\end{array}$ & 0.314 & $\begin{array}{l}42 \\
(27.5)\end{array}$ & $23(31.5)$ & $12(29.3)$ & $9(36.0)$ & $4(19.0)$ & $4(26.7)$ & 0.849 \\
\hline TET & $6(27.3)$ & $1(7.1)$ & $1(7.7)$ & - & 0.219 & $\begin{array}{l}23 \\
(15.0)\end{array}$ & $12(16.4)$ & $3(7.3)$ & $1(4.0)$ & $1(4.8)$ & - & 0.293 \\
\hline$C$ & $2(9.1)$ & 0 & 0 & 0 & 0.641 & $4(2.6)$ & $2(2.7)$ & $3(7.3)$ & 0 & $1(4.8)$ & - & 0.437 \\
\hline$C A Z$ & - & $1(7.1)$ & - & - & - & $4(2.6)$ & $4(5.5)$ & 0 & - & $1(4.8)$ & $3(20.0)$ & 0.026 \\
\hline CTX & $2(9.1)$ & $3(21.4)$ & $1(7.7)$ & $\begin{array}{l}3 \\
(33.3)\end{array}$ & 0.302 & $\begin{array}{l}33 \\
(21.6)\end{array}$ & $29(39.7)$ & $9(22.0)$ & $4(16.0)$ & $11(52.4)$ & $7(46.7)$ & 0.002 \\
\hline NAL & - & $1(7.1)$ & - & $\begin{array}{l}2 \\
(22.2)\end{array}$ & 0.538 & $\begin{array}{l}42 \\
(27.5)\end{array}$ & $16(21.9)$ & - & $4(16.0)$ & $8(38.1)$ & $7(46.7)$ & 0.159 \\
\hline ERY & 0 & - & - & - & - & - & - & $8(19.5)$ & - & - & - & - \\
\hline PEN & - & - & - & - & - & - & - & - & - & - & - & - \\
\hline CLI & $2(9.1)$ & - & - & - & - & - & - & $3(7.3)$ & - & - & - & - \\
\hline AMK & 0 & $1(7.1)$ & $3(23.1)$ & $1(11.1)$ & 0.071 & $\begin{array}{l}23 \\
(15.0)\end{array}$ & $13(17.8)$ & $6(14.6)$ & $5(20.0)$ & $2(9.5)$ & 0 & 0.550 \\
\hline
\end{tabular}

AMP - ampicillin, AMC - amoxicillin \& clavulanic acid, CRO - ceftriaxone, CXM - cefuroxime, AZM - azithromycin, AMK - amikacin, MEM - meropenem, SXT trimethoprim/sulfamethoxazole, CIP - ciprofloxacin, GEN - gentamicin, TET - tetracycline, C - chloramphenicol, CAZ - ceftazidime, CTX - cefotaxime and NAL nalidixic acid, ERY - erythromycin, penicillin and CLI - clindamycin 
laboratories had low detections because of the use of only culture methods which is less sensitive as compared to multiplex PCR. PCR is a fast, sensitive and reliable technique for simultaneous detection of different molecular targets in one reaction. Training and logistical support provided by the CDC to the TPHL enabled them to utilize this molecular approach to detect common etiological agents of meningitis from CSF in Ghana. It would be important for the other PHLs to be adequately resourced with molecular testing capacities to help them to appropriately detect and respond to infectious agents and outbreaks.

The high number of meningitis pathogens identified at the TPHL could also be due to the geographical location and catchment populations targeted which lies within the sSA meningitis belt. Cases of meningitis are frequently reported from the Northern part of Ghana, where TPHL is situated, especially during the hot dry seasons (December - March, and August), leading to several meningitis outbreaks. Unlike CSF samples, other specimens such as urine, stool and blood did not show such seasonal trend. It is an established fact that cerebrospinal meningitis is an infectious disease which is commonly impacted by climate, specifically hot climate [10]. The five Northern regions (Upper East, Upper West, Savannah, North-East and Northern regions) are the most hottest regions in Ghana and the weather worsens during the period between December and June, and this results in a number of CSM outbreaks in Northern Ghana, as previously reported [10, 33]. Several studies have indicated that climatic conditions characterized by dry winds, dust storms, low humidity and cold nights considerably diminish the local immunity of the pharynx thereby increasing the risk of meningitis [3436]. These climatic conditions are typically found in the Northern Ghana during the dry season, and this likely explains why CSF samples were largely collected during the peak dry seasons compared to the other sample types.

Almost all CSF pathogens (145/148; 98\%) recorded in this study emanated from TPHL. Streptococcus pneumoniae was the most isolated pathogen from CSF, consistent with previous data from Brong Ahafo region [37], about $210 \mathrm{~km}$ away from Tamale. This Global Health Security pathogen is the leading cause of bacterial meningitis, with an average mortality rate of $25 \%$, despite effective antibiotic therapy and improved intensive care facilities [38]. Bacterial meningitis outbreaks are common in countries located in the Africa's meningitis belt [39]. Rapid detection of the etiology of these outbreaks can lead to targeted public health interventions. Building and sustaining laboratory capacity in countries where meningitis outbreaks are common will be critical to ensure rapid and effective response to these outbreaks.
Global emergence and spread of antibiotic resistant strains of bacteria is still a major health problem. CfHSS provided training in the performance and interpretation of antimicrobial susceptibility tests to all the PHLs. Guidelines and protocols by Clinical and Laboratory Standards Institute (CLSI) were made available to the PHLs and all staff were adequately trained in the use of these documents. Antimicrobial susceptibility tests from blood cultures in this study revealed high resistance (35-55\%) of S. aureus, K. pneumoniae and E. coli to gentamicin. This drug is commonly used to treat wide range of Gram-negative and some Gram-positive infections due to its antimicrobial efficacy, widespread availability and low cost [40]. However, the present report shows increase in resistance to this vital drug, consistent with data reported by Ababneh and colleagues [41]. Escherichia coli in urine showed high resistance to drugs such as ciprofloxacin (39.2\%) and ampicillin (34\%). These are historically useful antibiotics for the treatment of UTIs [42]. Also, high rate of Klebsiella spp. resistance (39.7\%) to the 3rd generation cephalosporin cefotaxime is of great concern. Resistance to 3rd generation cephalosporins such as cefotaxime, ceftazidime and ceftriaxone serves as surrogate marker for detection of extendedspectrum beta-lactamases (ESBL) [43]. There have been reported cases of increasing trend of Klebsiella resistance to these 3rd generation cephalosporins [44, 45]. Third generation cephalosporin resistance leaves clinicians with limited options for treating patients with gram-negative infections, and as a result, relatively expensive drugs within the carbapenem class are usually considered the treatment of choice [45].

A limitation of this study was the inability to examine for the presence of ESBL phenotypes in the bacterial isolates which were resistant to the 3rd generation cephalosporins. A suggested approach would be to conduct double-disc diffusion synergy test for phenotypic confirmation of organisms possibly encoding ESBL. Another limitation was the exclusion of laboratory detection of viral and parasitic infections. This was due to restricted CDC-Ghana PHL budget for the project. Further support is therefore needed for capacity building in the detection of viruses and parasites in the three zonal PHLs.

\section{Conclusion}

Isolation and proper identification of aetiological agents in bacterial infection are of great importance. Partner and NGOs are encouraged to contribute their quota to help strengthen PHLs in sub-Saharan Africa. Outcome of this report clearly indicates that with routine and effective laboratory trainings, equipment and reagents support, detection of bacteria pathogens could be greatly enhanced, and the right antimicrobial therapy administered. 


\section{Abbreviations}

GHSA: Global Health Security Agenda; IHR: International Health Regulations: AST: Antimicrobial Susceptibility Testing; PHL: Public Health Laboratories; CDC: Centers for Disease Control and Prevention; APHL: Association of Public Health Laboratories; CfHSS: Centre for Health System Strengthening; NGO: Non-Governmental Organization; WHO: World Health Organization; SOP: Standard Operating Procedure; QMS: Quality Management System; API: Analytical Profile Index; ERC: Ethics Review Committee; GHS: Ghana Health Service; CLED: Cysteine Lactose Electrolyte-Deficient; XLD: Xylose Lysine Deoxycholate; MSA: Manitol Salt Agar; TCBS: Thiosulphate Citrate Bile Salt Sucrose; SMAC: Sorbitol-MacConkey Agar; PCR: Polymerase Chain Reaction

\section{Acknowledgements}

We are thankful to staff of all the Public Health Laboratories for assisting with sample collection and processing. We also thank the Ghana Health Service and US CDC for supporting this study.

\section{Availability of data and material}

The datasets used and/or analyzed during the current study are available from the corresponding author on reasonable request.

\section{Authors' contributions}

All authors have read and approved the manuscript. MO, BN, DJS conceptualized and designed the experiments. EKM, AAK, FKS performed the experiments. MO, GA, BN collected and analyzed the data. GA, MO, BN wrote the paper. BN, GA, MO, SE, LMR, KA, DO critically reviewed the manuscript.

\section{Funding}

Funding was provided by CDC through the Association of Public Health Laboratories, USA and Centre for Health Systems Strengthening, Ghana.

\section{Declarations}

\section{Ethics approval and consent to participate}

Permission to access raw data from the three Public Health Laboratories was granted by the heads of the respective laboratories. Data collected from these laboratories were anonymized prior to its use. All protocols related to data collection and analysis were reviewed and approved by the Ethics Review Committee (ERC) of the Ghana Health Service (GHS) (Approval number: GHS-ERC008/03/20).

\section{Consent for publication}

Not applicable.

\section{Competing interests}

The authors declare that they have no competing interests.

\section{Author details}

${ }^{1}$ Centre for Health Systems Strengthening, Kumasi, Ghana. ${ }^{2}$ Department of Medical Diagnostics, Kwame Nkrumah University of Science and Technology, Kumasi, Ghana. ${ }^{3}$ African Field Epidemiology Network, Accra, Ghana. ${ }^{4}$ Sekondi Public Health Laboratory, Ghana Health Service, Sekondi, Ghana. ${ }^{5}$ Tamale Public Health Laboratory, Ghana Health Service, Tamale, Ghana. ${ }^{6}$ Kumasi Public Health Laboratory, Ghana Health Service, Kumasi, Ghana. ${ }^{7}$ Association of Public Health Laboratories, Silver Springs, MD, USA. ${ }^{8}$ National Public Health and Reference Laboratory, Accra, Ghana.

\section{Received: 23 August 2020 Accepted: 18 March 2021}

Published online: 25 March 2021

\section{References}

1. Fair JM. Biological engagement programs: reducing threats and strengthening global health security through scientific collaboration. Front Public Health. 2017:5:148. https://doi.org/10.3389/fpubh.2017.00148.

2. Ventola CL. The antibiotic resistance crisis: part 1: causes and threats. Pharm Ther. 2015;40(4):277-83.

3. WHO. Essential medicines and health products: global priority list of antibiotic-resistant bacteria to guide research, discovery, and development of new antibiotics. Available online at: http://www.who.int/medicines/ publications/global-priority-list-antibiotic-resistant-bacteria. Accessed 16 May 2020.

4. Levy SB. The challenge of antibiotic resistance. Sci Am. 1998;278(3):46-53. https://doi.org/10.1038/scientificamerican0398-46.

5. Zaman SB, Hussain MA, Nye R, Mehta V, Mamun KT, Hossain N. A review on antibiotic resistance: alarm bells are ringing. Cureus. 2017:9(6).

6. The Global Fund, The Global Fund to Fight AIDS, Tuberculosis and Malaria Global Health. Available online at: https://www.theglobalfund.org/media/ 5431/corporate_theglobalfund_brochure_en. Accessed 1 July 2020.

7. WHO: Joint External Evaluation of IHR Core Capacities of the Republic of Ghana. Geneva: Licence: CC BY-NC-SA 3.0 IGO. In., vol. Licence: CC BY-NC-SA 3.0 IGO; 2017.

8. Buchan BW, Ledeboer NA. Emerging technologies for the clinical microbiology laboratory. Clin Microbiol Rev. 2014;27(4):783-822. https://doi. org/10.1128/CMR.00003-14.

9. Ministry-of-Health: Standard Treatment Guidelines. Ministry of Health. Republic of Ghana. Sixth Edition. 1-479. 2010.

10. Codjoe SNA, Nabie VA. Climate change and cerebrospinal meningitis in the Ghanaian meningitis belt. Int J Environ Res Public Health. 2014;11(7):692339. https://doi.org/10.3390/ijerph110706923.

11. CLSI: Performance Standards for Antimicrobial Susceptibility Testing. CLSI supplement M100. Wayne, PA., 28th ed. edn: Clinical and Laboratory Standards Institute; 2018.

12. Monitoring and statistics. Available at: http://www.unicef.org/statistics. Date accessed 01 October 2019.

13. WHO: The world health report 2004_changing history. Geneva: WHO, 2004 Available at: http://www.who.int/whr/2004/en/index.html. Date accessed 02 Octtober 2019. 2004

14. Berkley JA, Lowe BS, Mwangi I, Williams T, Bauni E, Mwarumba S, et al. Bacteremia among children admitted to a rural hospital in Kenya. N Engl J Med. 2005;352(1):39-47. https://doi.org/10.1056/NEJMoa040275.

15. Dramowski A, Cotton MF, Rabie H, Whitelaw A. Trends in paediatric bloodstream infections at a south African referral hospital. BMC Pediatr. 2015;15(1):33. https://doi.org/10.1186/s12887-015-0354-3.

16. Graham SM. Nontyphoidal salmonellosis in Africa. Curr Opin Infect Dis. 2010; 23(5):409-14. https://doi.org/10.1097/QCO.0b013e32833dd25d.

17. Oliveira J, Reygaert WC: Gram Negative Bacteria. In: StatPearls [Internet]. StatPearls Publishing; 2019.

18. Naber CK: Staphylococcus aureus bacteremia: epidemiology, pathophysiology, and management strategies. Clinical infectious diseases 2009, 48(Supplement_4):S231-S237.

19. Troidle L, Eisen T, Pacelli L, Finkelstein F. Complications associated with the development of bacteremia with Staphylococcus aureus. Hemodial Int. 2007;11(1):72-5. https://doi.org/10.1111/j.1542-4758.2007.00156.x.

20. Fowler VG, Miro JM, Hoen B, Cabell CH, Abrutyn E, Rubinstein E, et al. Staphylococcus aureus endocarditis: a consequence of medical progress. Jama. 2005;293(24):3012-21. https://doi.org/10.1001/jama.293.24.3012.

21. Shorr A, Lodise T. Burden of methicillin-resistant Staphylococcus aureus on healthcare cost and resource utilization. ISMR Update. 2006;1(2):1-12.

22. Petti CA, Polage CR, Quinn TC, Ronald AR, Sande MA. Laboratory medicine in Africa: a barrier to effective health care. Clin Infect Dis. 2006;42(3):377-82. https://doi.org/10.1086/499363.

23. Clinton WJ. Turning the tide on the AIDS pandemic. In: Mass Medical Soc. 2003.

24. Sabih A, Leslie SW: Complicated Urinary Tract Infections. In: StatPearls [Internet]. StatPearls Publishing; 2019.

25. Oladeinde $\mathrm{BH}$, Omoregie R, Olley M, Anunibe JA. Urinary tract infection in a rural community of Nigeria. N Am J Med Sci. 2011;3(2):75-7. https://doi. org/10.4297/najms.2011.375.

26. Medina M, Castillo-Pino E. An introduction to the epidemiology and burden of urinary tract infections. Ther Adv Urol. 2019;11:1756287219832172.

27. Flores-Mireles AL, Walker JN, Caparon M, Hultgren SJ. Urinary tract infections: epidemiology, mechanisms of infection and treatment options. Nat Rev Microbiol. 2015;13(5):269-84. https://doi.org/10.1038/nrmicro3432.

28. Al-Badr A, Al-Shaikh G. Recurrent urinary tract infections management in women: a review. Sultan Qaboos Univ Med J. 2013;13(3):359-67. https://doi. org/10.12816/0003256

29. Scholes D, Hooton TM, Roberts PL, Stapleton AE, Gupta K, Stamm WE. Risk factors for recurrent urinary tract infection in young women. J Infect Dis. 2000;182(4):1177-82. https://doi.org/10.1086/315827.

30. Franco AVM. Recurrent urinary tract infections. Best Pract Res Clin Obstet Gynaecol. 2005;19(6):861-73. https://doi.org/10.1016/j.bpobgyn.2005.08.003. 
31. Rezny BR, Evans DS: Vibrio parahaemolyticus. In: StatPearls [Internet]. StatPearls Publishing; 2018

32. Letchumanan V, Chan K-G, Lee L-H. Vibrio parahaemolyticus: a review on the pathogenesis, prevalence, and advance molecular identification techniques. Front Microbiol. 2014:5:705.

33. Belcher D, Sherriff A, Nimo K, Chew G, Voros A, Richardson W, et al. Meningococcal meningitis in northern Ghana: epidemiology and control measures. Am J Trop Med Hyg. 1977;26(4):748-55. https://doi.org/10.4269/a jtmh.1977.26.748.

34. Mueller JE, Yaro S, Madec Y, Somda PK, Idohou RS, Njanpop Lafourcade BM, et al. Association of respiratory tract infection symptoms and air humidity with meningococcal carriage in Burkina Faso. Tropical Med Int Health. 2008; 13(12):1543-52. https://doi.org/10.1111/j.1365-3156.2008.02165.x

35. Sultan B, Labadi K, Guégan J-F, Janicot S. Climate drives the meningitis epidemics onset in West Africa. PLoS Med. 2005;2(1):e6. https://doi.org/10.13 71/journal.pmed.0020006.

36. Hastenrath S: Climate dynamics of the tropics, vol. 8: Springer Science \& Business Media; 2012.

37. Letsa T, Noora CL, Kuma GK, Asiedu E, Kye-Duodu G, Afari E, et al. Pneumococcal meningitis outbreak and associated factors in six districts of Brong Ahafo region, Ghana, 2016. BMC Public Health. 2018;18(1):781. https://doi.org/10.1186/s12889-018-5529-z.

38. Parent du Chatelet I, Traore Y, Gessner B, Antignac A, Naccro B. Bacterial meningitis in Burkina Faso: surveillance using field-based polymerase chain reaction testing. Clin Infect Dis. 2005;40(1):17-25.

39. Aku FY, Lessa FC, Asiedu-Bekoe F, Balagumyetime P, Ofosu W, Farrar J, et al. Meningitis outbreak caused by vaccine-preventable bacterial pathogens-northern Ghana, 2016. MMWR Morb Mortal Wkly Rep. 2017; 66(30):806-10. https://doi.org/10.15585/mmwr.mm6630a2.

40. Rizzi MD, Hirose K. Aminoglycoside ototoxicity. Curr Opin Otolaryngol Head Neck Surg. 2007;15(5):352-7. https://doi.org/10.1097/MOO.0b013e3282ef772d.

41. Ababneh M, Harpe S, Oinonen M, Polk RE. Trends in aminoglycoside use and gentamicin-resistant gram-negative clinical isolates in US academic medical centers: implications for antimicrobial stewardship. Infect Control Hospital Epidemiol. 2012;33(6):594-601. https://doi.org/10.1086/665724.

42. Mazzulli T, Skulnick M, Small G, Marshall W, Hoban DJ, Zhanel GG, et al. Susceptibility of community gram-negative urinary tract isolates to mecillinam and other oral agents. Can J Infect Dis Med Microbiol. 2001; 12(5):289-92.

43. Bidell MR, Palchak M, Mohr J, Lodise TP. Fluoroquinolone and thirdgeneration-cephalosporin resistance among hospitalized patients with urinary tract infections due to Escherichia coli: do rates vary by hospital characteristics and geographic region? Antimicrob Agents Chemother. 2016; 60(5):3170-3. https://doi.org/10.1128/AAC.02505-15.

44. Lee J-a, Kang C-I, Joo E-J, Ha YE, Kang S-J, Park SY, et al. Epidemiology and clinical features of community-onset bacteremia caused by extendedSpectrum $\beta$-lactamase-producing Klebsiella pneumoniae. Microb Drug Resist. 2011;17(2):267-73. https://doi.org/10.1089/mdr.2010.0134.

45. Park SH. Third-generation cephalosporin resistance in gram-negative bacteria in the community: a growing public health concern. The Korean $J$ Intern Med. 2014;29(1):27-30. https://doi.org/10.3904/kjim.2014.29.1.27.

\section{Publisher's Note}

Springer Nature remains neutral with regard to jurisdictional claims in published maps and institutional affiliations.

Ready to submit your research? Choose BMC and benefit from:

- fast, convenient online submission

- thorough peer review by experienced researchers in your field

- rapid publication on acceptance

- support for research data, including large and complex data types

- gold Open Access which fosters wider collaboration and increased citations

- maximum visibility for your research: over $100 \mathrm{M}$ website views per year

At $\mathrm{BMC}$, research is always in progress.

Learn more biomedcentral.com/submissions 